\title{
МОЛОДЕЖЬ КАЛИНИНГРАДСКОЙ ОБЛАСТИ: РЕПРОДУКТИВНОЕ ПОВЕДЕНИЕ В ИСТОРИЧЕСКОЙ РЕТРОСПЕКТИВЕ И НА СОВРЕМЕННОМ ЭТАПЕ*
}

В статье рассматривается репродуктивное поведение молодых людей в возрасте 15-19 лет, проживающих на территории Калининградской области. Источниками информаџии для автора послужили архивные документы, материаль переписей населения, а также даннье текущей статистики на протяжении шестидесяти лет (1959-2019 г2.). На основе статистических показателей продемонстрирован прочесс постепенного сокращения удельного веса молодых людей обозначенной возрастной группь в составе населения региона. С одной стороны, это явилось следствием снижения рождаемости на протяжении рассматриваемого периода, с другой сторонь, оказало влияние на динамику рождаемости, особенно на современном этапе. Уделено особое внимание показателям рождаемости среди женщин моложе 20 лет. Был сделан вывод о том, что «вклад» самых молодых женщуин в воспроизводство населения области претерпел существенные изменения на протяжении шести десятилетий. Во многом это было обусловлено изменением отношения молодых людей к брачному статусу, о чем свидетельствуют показатели увеличения количества внебрачных связей и изменение количества и удельного веса детей, рожденных вне официально зарегистрированного брака. Таким образом, была установлена определенная связь между репродуктивным поведением и семейно-брачными установками молодежи.

Ключевые слова: Калининградская область, молодежь, репродуктивное поведение, репродуктивный возраст, семейно-брачные установки

Ссылка при цитировании: Зимовина Е.П. Молодежь Калининградской области: репродуктивное поведение в исторической ретроспективе и на современном этапе // Вестник антропологии, 2021. № 2. С. 110-127

Постановка проблемы. Молодежная тематика является одной из актуальных проблем современного российского общества. С одной стороны, молодежь представляет собой ту часть населения, которая принимает активное участие в общественно-политической жизни, занимается волонтерской деятельностью, демонстрирует прекрасные результаты в учебе, спорте, бизнесе и т.д. Наряду с этим, в молодежной

Зимовина Елена Павловна - к.и.н., старший научный сотрудник Социологической лаборатории, Балтийский федеральный университет им. И. Канта (236016 Калининград, А. Невского, 14). Эл. почта: ezimovina@kantiana.ru, zimelena@yandex.ru

*Статья подготовлена при поддержке РФФИ и БРФФИ в рамках научного проекта № 20-5900014/20 «Опыт лонгитюдных исследований идентичности и жизненных стратегий молодежи Калининградской и Гродненской областей» 
среде существуют острые проблемы социального характера - бытовая неустроенность, безработица, преступность, этническая и религиозная нетерпимость и т.д. Такая противоречивость молодежной проблематики нацеливает государство на поиск механизмов, способствующих купированию социальных проблем и направляющих энергию молодых людей в позитивное и продуктивное русло.

Одним из серьезных вопросов, на которые обращает внимание государство, является репродуктивное поведение молодежи. Проблема рассматривается в тесной увязке с текущей демографической ситуацией в стране и нацелена на решение, как минимум, двух основных задач: повышение рождаемости и укрепление семейно-брачных отношений. Так, в документе «Основы государственной молодежной политики Российской Федерации на период до 2025 года» среди приоритетных задач указана такая, как «создание благоприятных условий для молодых семей, направленных на повышение рождаемости, формирование ценностей семейной культуры и образа успешной молодой семьи, всестороннюю поддержку молодых семей» (Основы 2014: 10). А в недавно принятом Законе «О молодежной политике в Российской Федерации» одна из целей молодежной политики определена как «формирование культуры семейных отношений, поддержка молодых семей, способствующие улучшению демографической ситуации в Российской Федерации» (Федеральный 2020: 6).

Как видим, репродуктивное поведение и семейно-брачные ориентиры молодежи являются вопросами государственной важности, поскольку направлены на решение задач социально-демографического характера. В тоже время, деторождение и семья являются очень тонкими темами, которые касаются личной жизни молодых людей и зависят от сложившихся обстоятельств. Поэтому исследование изменений в репродуктивном поведении молодежи на протяжении длительного периода времени необходимо рассматривать как с позиции общепринятых норм на каком-либо этапе развития общества, так и с точки зрения индивидуального жизненного пути человека.

Объектом данного исследования является молодежь Калининградской области в возрасте 15-19 лет. Обозначенная возрастная группа представляет собой демографический потенциал общества, поскольку традиционно к репродуктивному возрасту относят женское население с 15 лет (Народонаселение 1994: 386). Девушки в возрасте 15-19 лет являются самыми младшими из женщин детородного возраста, и изучение их репродуктивного поведения представляется важным для понимания состояния и перспектив рождаемости в регионе. Кроме того, представители данного возраста имеют возможность вступления в официально зарегистрированный брак. Согласно Семейному Кодексу Российской Федерации, брачный возраст определяется с 18 лет, а в исключительных случаях - с 16 лет (Семейный 1995). Помимо этого, данные официальной статистики говорят о существовании как официально зарегистрированных, так и официально не зарегистрированных браков среди молодежи до 18 лет (Всероссийская 2010; Демографический 2018: 62-63). Так что некоторые представители исследуемых возрастов уже имеют опыт семейно-брачной жизни. В тоже время, рассматриваемая возрастная группа включает в себя как совершеннолетних, так и несовершеннолетних. Поэтому вопросы репродуктивного поведения и семейно-брачных отношений молодежи данной возрастной категории выходят за рамки историко-демографической проблемы и обретают социальную окраску.

Хронологические рамки данного исследования охватывают шесть десятилетий (1959-2019 гг.). В качестве отправной точки был определен 1959 г., когда в Кали- 
нинградской области была проведена первая советская перепись населения. К этому времени наладился статистический учет, полностью обновилось население региона и наметились основные тренды демографического развития.

Источниками информации послужили архивные документы, материалы переписей населения, а также данные текущей официальной статистики и нормативно-правовые акты.

Степень изученности проблемы. Вопросы демографического развития Калининградской области довольно хорошо изучены исследователями разных научных направлений. Проблемы заселения и освоения региона подробно рассмотрены в трудах историков (Костямов 2000; Костямов 2009; Манкевич 2009). Глубокий анализ демографических процессов представлен в работах географов (Федоров 2001; Федоров, Зверев 2020; Кузнецова 2016; Кузнецова, Сибирева 2020). Социологами были выявлены поколенческие различия в восприятии региона самим населением Калининградской области (Зимовина, Щекотуров, Кришталь 2020). Однако следует отметить недостаток научных публикаций, посвященных проблемам различных возрастных групп региона, в том числе и молодежи. И хотя по молодежной тематике проводились исследования (Григорьева, Мартынова 2016; Григорьева, Мартынова 2017; Зимовина 2019; Мартынова, Григорьева 2018), вопросы репродуктивного поведения в них не рассматривались. Следует сделать акцент на том, что во всероссийском масштабе изучение молодежной проблематики в академическом сообществе идет довольно активно (Гориков, Шереги 2010; Гориков, Шереги 2020; Молодежь 2016). При этом анализируются и вопросы репродуктивного поведения (Захарова, Акопян, Харченко 2002; Захаров, Митрофанова 2014; Козырева, Леэнина 2014; Митрофанова 2020).

Основная задача данной работы - проследить эволюцию репродуктивного поведения молодежи Калининградской области на протяжении шести десятилетий (1959-2019 гг.). В связи с этим были сформулированы следующие исследовательские вопросы: как изменялась численность молодого населения области; какие факторы оказали влияли на трансформацию репродуктивного поведения молодежи; чем была обусловлена модификация семейно-брачных установок молодых людей.

Общая характеристика демографических процессов в Калининградской области. Калининградская область является особенным регионом Российской Федерации. Она была образована в 1946 г. на той части территории Восточной Пруссии, которая в результате международных договоренностей была передана Советскому Союзу. На протяжении первого послевоенного десятилетия население региона полностью обновилось: граждане Германии покинули область, фронтовики были демобилизованы, а на новую территорию РСФСР было организованно массовое переселение советских людей (Костямов 2009: 97, 170-172).

В демографическом развитии Калининградской области можно выделить несколько этапов. Первый этап (1946-1998 гг.) характеризовался ежегодным ростом численности населения, который был обусловлен периодически меняющимися факторами. Так, до середины 1950-х годов население увеличивалось за счет миграционного прироста (Костяшов 2009: 89-90). С середины 1950-х и вплоть до конца 1980-х годов динамику численности определял естественный прирост. В 1990-е годы единственным источником пополнения численности населения вновь становится миграционный прирост (особенно с 1992 г., когда в Калининградской области утвердилась естественная убыль, см.: таблицу 1). 
Второй этап (1999-2006 гг.) был непродолжительным, но важным временным отрезком. Именно в эти годы было зафиксировано сокращение численности населения Калининградской области. Причем произошло это за счет того, что увеличившиеся показатели естественной убыли стали перекрывать снизившиеся показатели миграционного прироста (таблица 1).

Таблица 1

Компоненты изменения численности населения Калининградской области (тысяч человек)

\begin{tabular}{|c|c|c|c|c|c|c|c|c|c|}
\hline \multirow[b]{2}{*}{ Год } & \multirow{2}{*}{ 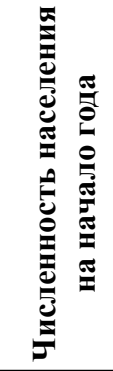 } & \multicolumn{3}{|c|}{$\begin{array}{l}\text { компоненты изменения } \\
\text { численности населения }\end{array}$} & \multirow[b]{2}{*}{ Год } & \multirow{2}{*}{ 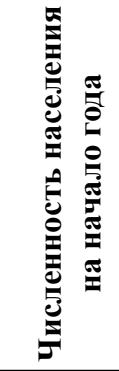 } & \multicolumn{3}{|c|}{$\begin{array}{l}\text { компоненты изменения } \\
\text { численности населения }\end{array}$} \\
\hline & & 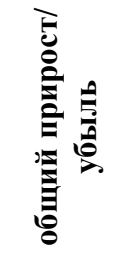 & 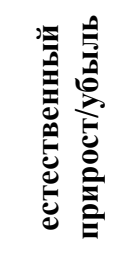 & 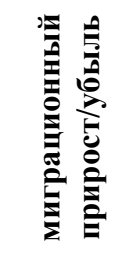 & & & 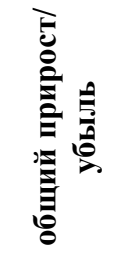 & 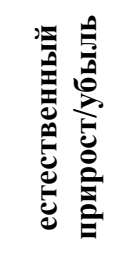 & 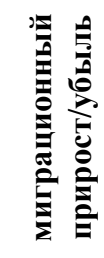 \\
\hline 1959 & 610,3 & 21,7 & 12,1 & 9,6 & 1990 & 878,2 & 8,7 & 2,5 & 6,2 \\
\hline 1960 & 632,0 & 18,0 & 12,4 & 5,6 & 1991 & 886,9 & 7,2 & 1,6 & 5,6 \\
\hline 1961 & 650,0 & 3,4 & 11,3 & $-7,9$ & 1992 & 894,1 & 12,0 & $-0,6$ & 12,6 \\
\hline 1962 & 653,4 & 4,2 & 10,1 & $-5,9$ & 1993 & 906,1 & 7,0 & $-4,1$ & 11,1 \\
\hline 1963 & 657,6 & 24,4 & 9,4 & 15,0 & 1994 & 913,1 & 13,3 & $-5,1$ & 18,4 \\
\hline 1964 & 682,0 & 18,9 & 8,9 & 10,0 & 1995 & 926,4 & 5,8 & $-4,7$ & 10,5 \\
\hline 1965 & 700,9 & 15,6 & 8,1 & 7,5 & 1996 & 932,2 & 3,4 & $-4,8$ & 8,2 \\
\hline 1966 & 716,5 & 1,9 & 7,6 & $-5,7$ & 1997 & 935,6 & 7,8 & $-5,2$ & 13,0 \\
\hline 1967 & 718,4 & 3,4 & 6,9 & $-3,5$ & 1998 & 943,4 & 17,8 & $-5,0$ & 13,0 \\
\hline 1968 & 721,8 & 2,1 & 6,4 & $-4,3$ & 1999 & 961,2 & $-2,4$ & $-6,4$ & 3,7 \\
\hline 1969 & 723,9 & 7,7 & 6,5 & 1,2 & 2000 & 958,8 & $-1,3$ & $-7,0$ & 5,7 \\
\hline 1970 & 731,6 & 8,2 & 6,9 & 1,3 & 2001 & 957,5 & $-2,1$ & $-7,8$ & 5,7 \\
\hline 1971 & 739,8 & 8,6 & 7,4 & 1,2 & 2002 & 955,4 & $-1,3$ & $-8,0$ & 6,7 \\
\hline 1972 & 748,4 & 9,9 & 7,6 & 2,3 & 2003 & 954,1 & $-6,2$ & $-8,3$ & 2,1 \\
\hline 1973 & 758,3 & 8,7 & 7,3 & 1,4 & 2004 & 947,9 & $-5,8$ & $-8,5$ & 2,7 \\
\hline 1974 & 767,0 & 7,2 & 7,2 & 0,0 & 2005 & 942,1 & $-5,5$ & $-8,6$ & 3,1 \\
\hline 1975 & 774,2 & 5,4 & 6,9 & $-1,5$ & 2006 & 936,6 & $-2,3$ & $-6,7$ & 4,4 \\
\hline 1976 & 779,6 & 10,5 & 7,1 & 3,4 & 2007 & 934,3 & 1,0 & $-4,2$ & 5,2 \\
\hline 1977 & 790,1 & 7,7 & 7,0 & 0,7 & 2008 & 935,3 & 1,3 & $-3,8$ & 5,1 \\
\hline 1978 & 797,8 & 9,1 & 6,5 & 2,6 & 2009 & 936,6 & 2,0 & $-2,8$ & 4,8 \\
\hline 1979 & 806,9 & 4,7 & 5,8 & $-1,1$ & 2010 & 938,6 & 3,2 & $-2,6$ & 5,8 \\
\hline 1980 & 811,6 & 4,4 & 5,4 & $-1,0$ & 2011 & 941,8 & 5,0 & $-1,4$ & 6,4 \\
\hline 1981 & 816,0 & 3,4 & 5,4 & $-2,0$ & 2012 & 946,8 & 8,0 & $-0,7$ & 8,7 \\
\hline 1982 & 819,4 & 1,7 & 5,4 & $-3,7$ & 2013 & 954,8 & 8,3 & $-0,6$ & 8,9 \\
\hline 1983 & 821,1 & 8,0 & 6,2 & 1,8 & 2014 & 963,1 & 5,8 & $-0,6$ & 6,4 \\
\hline
\end{tabular}


Таблица 1 (продолжение)

\begin{tabular}{|c|c|c|c|c|c|c|c|c|c|}
\hline \multirow[b]{2}{*}{ Год } & \multirow[b]{2}{*}{ 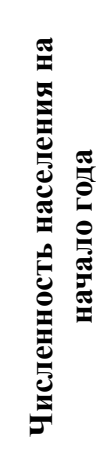 } & \multicolumn{3}{|c|}{$\begin{array}{l}\text { компоненты изменения } \\
\text { численности населения }\end{array}$} & \multirow[b]{2}{*}{ Год } & \multirow[b]{2}{*}{ 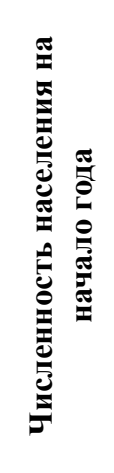 } & \multicolumn{3}{|c|}{$\begin{array}{l}\text { компоненты изменения } \\
\text { численности населения }\end{array}$} \\
\hline & & 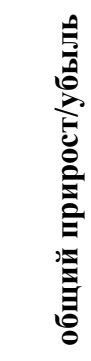 & 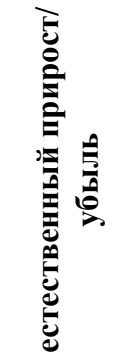 & 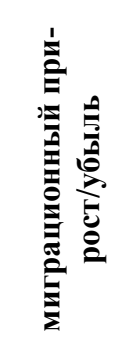 & & & 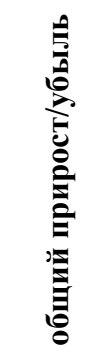 & 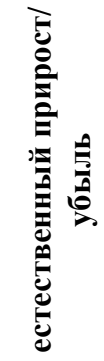 & 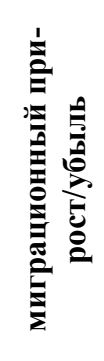 \\
\hline 1984 & 829,1 & 9,1 & 5,6 & 3,5 & 2015 & 968,9 & 7,5 & $-0,4$ & 7,9 \\
\hline 1985 & 838,2 & 8,3 & 5,4 & 2,9 & 2016 & 976,4 & 9,8 & $-0,1$ & 9,9 \\
\hline 1986 & 846,5 & 9,3 & 6,3 & 3,0 & 2017 & 986,2 & 8,4 & $-1,5$ & 9,9 \\
\hline 1987 & 855,8 & 6,9 & 6,3 & 0,6 & 2018 & 994,6 & 7,6 & $-1,9$ & 9,5 \\
\hline 1988 & 862,7 & 8,6 & 5,5 & 3,1 & 2019 & 1002,2 & 10,3 & $-2,7$ & 13,0 \\
\hline 1989 & 871,3 & 6,9 & 3,9 & 3,0 & 2020 & 1012,5 & $\ldots$ & $\ldots$ & $\ldots$ \\
\hline
\end{tabular}

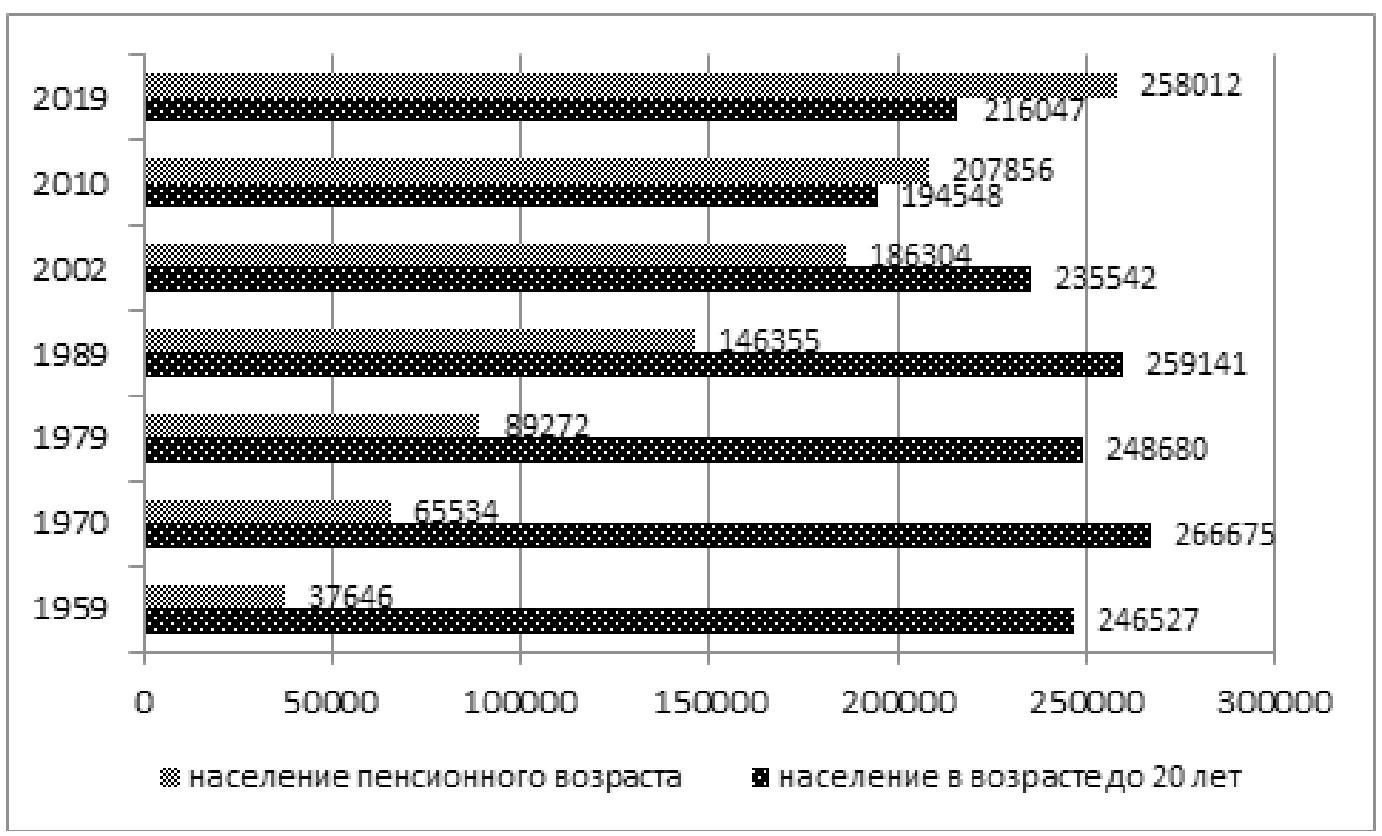

Рис. 1. Возрастная структура населения Калининградской области по данным переписей населения и сведениям на начало 2019 г.

Наконец, третий этап (2007-2020 гг.) продемонстрировал новые тенденции в развитии населения области: сохранение естественной убыли, рост показателей сальдо миграции и, как результат, «вторая волна» увеличения численности населения (таблица 1). Во многом, это является результатом предпринятых государством мер по стимулированию рождаемости (формирование материнского капитала, низкие ипотечные ставки для семей с детьми, региональные и федеральные программы демографическо- 
го развития и т.д.), а также привлечению русского и русскоязычного населения из-за рубежа (реализация Программы переселения соотечественников, а также Концепции государственной миграционной политики и т.д.).

Таким образом, население Калининградской области представляет собой уникальное сообщество, которое сформировалось в относительно короткий исторический период и развивалось в русле общероссийских тенденций, хотя для региона характерны и специфические тренды социально-демографического развития.

Трансформация возрастной структуры населения Калининградской области. Возрастная структура является своеобразной «матрицей», которая дает представление о состоянии населения на определенную дату, свидетельствует об особенностях его развития на предшествующих этапах и позволяет прогнозировать социально-демографические процессы. Проанализировать процесс изменения возрастной структуры в исторической ретроспективе возможно на основе данных переписей. В 1959 г. первая советская перепись населения Калининградской области зафиксировала динамичный рост численности населения, а также «молодую» возрастную структуру: доля детей и молодежи до 20 лет составляла 40,4\%; удельный вес людей пенсионного возраста $6,2 \%$ (рисунок 1). Сведения, полученные в ходе последующих переписей, демонстрируют активный процесс старения населения региона - соотношение пенсионеров и молодежи до 20 лет в 1970 г. составило 9,0\% и 36,4\%; в 1979 г. - 11,0\% и 30,8\%; 1989 г. $-16,8 \%$ и $29,7 \% ; 2002$ г. - 19,5\% и 24,7\%; 2010 г. - 22,1\% и 20,7\%, соответственно (рис. 1). По состоянию на начало 2019 г. более четверти населения Калининградской области было представлено людьми пенсионного возраста $(25,7 \%)$ и лишь пятую часть составляли дети и молодежь до 20 лет - 21,6\% (рис. 1).

На протяжении исследуемого периода численность молодого населения области не отличалась стабильностью (рис. 2). Согласно данным переписи 1959 г. удельный вес юношей и девушек в возрасте 15-19 лет составил 7,3\% от всей численности населения области (рис. 2) и 18,8\% от численности молодых людей в возрасте до 20 лет. Это были дети, родившиеся в годы войны и представлявшие одно из самых малочисленных поколений в демографической истории Калининградской области. Кроме того, это были уроженцы других регионов Советского Союза. Перепись 1970 г. зафиксировала иную ситуацию: доля молодежи 15-19 лет увеличилась до 10,4\% (рис. 2), а в составе населения моложе 20 лет возросла до 28,6\%. В данном случае речь идет о поколениях, родившихся в первой половине 1950-х годов, когда показатели рождаемости оставались еще довольно высокими (таблица 2). Резкое снижение рождаемости в конце 1950-х - первой половине 1960-х годов сказалось на соотношении возрастных групп Калининградской области ко времени проведения переписи 1979 г. Так, удельный вес молодежи 15-19 лет сократился до 8,9\%, а в 1989 г. до 7,7\% (рисунок 2). Отметим и изменение их удельного веса в составе населения до 20 лет: 1979 г. - 29,1\%, 1989 г. - 26,0\%. Таким образом, на протяжении 1970-1980-х годов четко прослеживается тенденция сокращения численности и удельного веса населения 15-19 лет, что было обусловлено окончательным утверждением низких показателей рождаемости (таблица 2). В связи с этим, парадоксальной кажется ситуация по данным переписи 2002 г., когда доля молодежи 15-19 лет вновь увеличилась до 9,2\% (рис. 2). Это было связано с кратковременным ростом рождаемости с 1983 по 1987 гг. (таблица 2). В результате, в 2002 г. в составе населения младше 20 лет доля 15-19-летних составила 37,1\%. Напротив, перепись 2010 г. демонстрирует резкое 
сокращение доли населения 15-19 лет (рис. 2) в результате снижения рождаемости в первой половине 1990-х годов (таблица 2). К этому времени уменьшилась и доля 15-19-летних в составе населения до 20 лет (30,2\%). Наконец, данные текущей статистики на начало 2019 г. дают представление о значительном снижении как численности, так и доли населения 15-19 лет (рис. 2). Причем как в региональном разрезе, так и во всероссийском масштабе (Территориальный 2019; Федеральная 2019). И это несмотря на то, что начало 2000-х годов было ознаменовано некоторым ростом рождаемости (таблица 2) и положительным сальдо миграции людей в возрасте 1519 лет (Демографический 2018: 107-108).

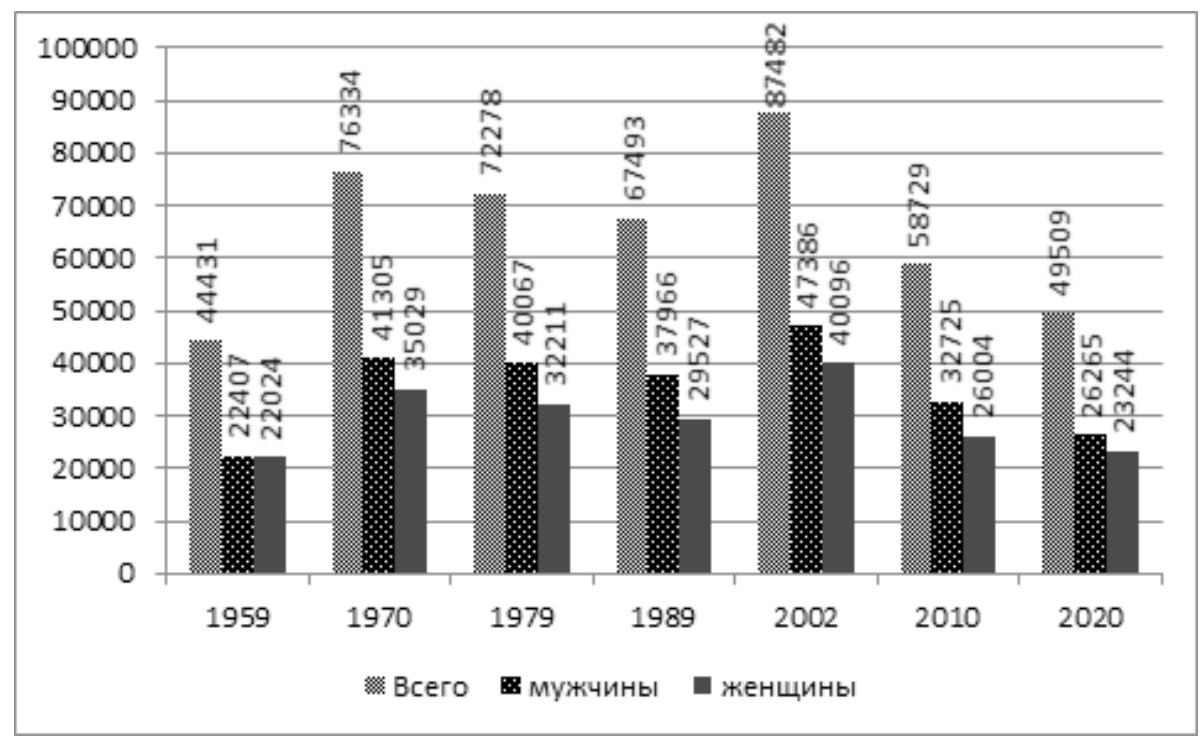

Рис. 2. Население России и Калининградской области в возрасте 15-19 лет (по данным переписей населения 1959, 1970, 1979, 1989, 2002 и 2010 г2., и данным текущей статистики на начало 2019 г.).

Проведенный анализ динамики численности и удельного веса молодежи 1519 лет на протяжении шестидесяти лет расширяет представление о трансформации возрастной структуры населения Калининградской области, а также способствует пониманию демографических предпосылок и демографических последствий таких изменений.

Изменения в демографическом поведении молодежи Калининградской облаcmu. Выявить особенности репродуктивного поведения разных возрастных групп возможно опираясь на сведения о численности женщин детородного возраста (1549 лет). Статистические данные говорят о постепенном снижении их удельного веса: 1959 г. $-57,8 \%$; 1970 г. $-58,4 \%$; 1979 г. $-54,3 \%$; 1989 г. - 48,0\%; 2002 г. - 51,9\%; 2010 г. - 48,2\%; 2019 г. - 44,1\% (Демоскоп 2020; Территориальный 2019). В данном случае мы видим результат тех демографических процессов, которые были описаны выше. Что касается женщин моложе 20 лет, то их численность и доля в составе женщин репродуктивного возраста также изменялись в течение рассматриваемого периода: 1959 г. - 11,3\%; 1970 г. - 15,7\%; 1979 г. - 14,1\%; 1989 г. - 13,6\%; 2002 г. 15,5\%; 2010 г. - 10,8\%; 2019 г. - 9,4\% (Демоскоп 2020; Территориальный 2019). Во 
многом это предопределило тенденции рождаемости в Калининградской области, которые на протяжении рассматриваемого периода (1959-2019 гг.) менялись неоднократно (таблица 2). Однако для всех возрастных групп женщин были характерны свои особенности на различных этапах развития региона.

Показатели рождаемости у женщин до 20 лет были крайне нестабильными на протяжении шестидесяти лет и имели свою специфику. Анализ данных позволил выделить несколько этапов в тенденциях рождаемости среди женщин этого возраста. Так, с 1958 по 1963 гг. наблюдалось ежегодное сокращение численности новорожденных; с 1964 по 1978 гг. происходил процесс стремительного увеличения количества родившихся (за исключением отдельно взятых годов); с 1979 по 1981 гг. ежегодное количество рождений становится несколько меньше; с 1982 по 1986 гг. идет некий процесс стабилизации, когда показатели рождаемости кардинально не меняются; с 1987 по 1990 гг. зафиксирован «всплеск» количества новорожденных; однако, с 1991 г. и до сегодняшних дней идет неуклонный тренд - снижение количества новорожденных у самых молодых женщин репродуктивного возраста (таблица 2). Изменялась и доля новорожденных у женщин моложе 20 лет. Если в конце 1950-х - середине 1960-х годов показатели удельного веса родившихся были мизерными, то с конца 1960-х годов становятся весьма ощутимыми, причем на протяжении длительного времени - почти сорока лет. Однако с 2007 г. показатели вновь стали ежегодно сокращался (таблица 2). Кроме того, на определенных этапах (19751979 гг. и 1990-1999 гг.) по количеству и удельному весу родившихся детей, женщины моложе 20 лет занимали «третье место», уступая лишь женщинам в возрасте 20-24 лет и 25-29 лет. Однако с 2000 г. они переместились на «четвертое место», совсем немного уступая матерям в возрасте 30-34 лет; с 2009 г. оказались на «пятом месте», пропустив вперед всех двадцати- и тридцатилетних женщин; наконец, с 2017 г. занимают «шестое место», опережая лишь женщин в возрасте 45-49 лет (Демографический 2000: 46-47; Демографический 2009: 37-38; Демографический 2018: 70). Таким образом, на сегодняшний день показатели рождаемости среди женщин до 20 лет являются очень низкими, что обусловлено как их малочисленностью, так и определившимся общим вектором снижения рождаемости. Немаловажную роль играет и осведомленность молодежи о средствах контрацепции.

В среднем, около 95\% новорожденных у матерей моложе 20 лет были первенцами. Однако анализ повозрастных показателей рождаемости показывает, что случаи появления на свет второго, третьего и даже четвертого ребенка у юных матерей, фиксировались ежегодно (ГАКО).

Интересная модификация произошла и с таким явлением, как внебрачная рождаемость. Прежде чем перейти к ее анализу, необходимо дать пояснения о формах сбора информации по данной категории новорожденных. В статистических отчетах до 1968 г., помимо сведений об общем количестве родившихся за год, зафиксированы данные о младенцах, в отношении которых в актах о рождении отсутствует запись об отце. С 1969 эта формулировка была заменена на информацию о родившихся, зарегистрированных по заявлению матери. Именно эти показатели мы рассматривали как данные о количестве родившихся вне брака (таблица 2). С 1992 г. в документах появляются сведения об учете новорожденных по нескольким категориям: всего родившихся, родившиеся в браке, родившиеся вне брака (в т.ч. зарегистрированные по совместному заявлению родителей и зарегистрированные по заявлению матери) 
(ГАКО; Демографический 2009; Демографический 2018). В определенной степени такие изменения были обусловлены юридическими аспектами. Так, 27 июня 1968 г. в СССР был принят Закон, регламентирующий отношения в браке и семье. В статье 17 («Запись родителей в книгах записей рождений») было прописано: «Если родители не состоят в браке между собой, запись о матери ребенка производится по заявлению матери, а запись об отце ребенка - по совместному заявлению отца и матери ребенка, либо отец записывается согласно решению суда» (Закон). В постсоветский период Семейный Кодекс Российской Федерации был принят 8 декабря 1995 г. В статье 48 («Установление происхождения ребенка») указано: «Отцовство лица, не состоящего в браке с матерью ребенка, устанавливается путем подачи в орган записи актов гражданского состояния совместного заявления отцом и матерью ребенка... При наличии обстоятельств, дающих основания предполагать, что подача совместного заявления об установлении отцовства может оказаться после рождения ребенка невозможной или затруднительной, родители будущего ребенка, не состоящие между собой в браке, вправе подать такое заявление в орган записи актов гражданского состояния во время беременности матери. Запись о родителях ребенка производится после рождения ребенка (Семейный 1995).

Таблица 2

Сведения о родившихся в Калининградской области у женщин моложе 20 лет по национальности и брачному статусу матери

\begin{tabular}{|c|c|c|c|c|c|c|c|c|c|c|c|c|c|}
\hline \multirow{3}{*}{ Год } & \multirow{3}{*}{ 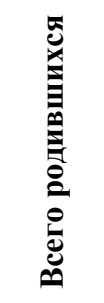 } & \multirow{2}{*}{\multicolumn{2}{|c|}{$\begin{array}{c}\text { в т.ч. у } \\
\text { женщин до } \\
20 \text { лет }\end{array}$}} & \multirow{2}{*}{\multicolumn{2}{|c|}{$\begin{array}{c}\text { в т.ч. } \\
\text { родившиеся } \\
\text { вне брака } \\
\text { русские }\end{array}$}} & \multicolumn{8}{|c|}{ в т.ч. родившиеся по национальности матери } \\
\hline & & & & & & \multicolumn{2}{|c|}{ украинцы } & \multicolumn{2}{|c|}{ белорусы } & \multicolumn{2}{|c|}{ литовцы } & \multirow[b]{2}{*}{ абсc. } & \multirow[b]{2}{*}{$\%$} \\
\hline & & аб̆c. & $\%$ & абс. & $\%$ & абсc. & $\%$ & абс. & $\%$ & абсс. & $\%$ & & \\
\hline 1959 & 15179 & 697 & 4,6 & 119 & 17,1 & 523 & 75,0 & 36 & 5,2 & 77 & 11,0 & $\ldots$ & $\ldots$ \\
\hline 1960 & 15379 & 683 & 4,4 & 108 & 15,8 & 490 & 71,7 & 34 & 5,0 & 100 & 14,6 & 40 & 5,9 \\
\hline 1961 & 14252 & 577 & 4,0 & 89 & 15,4 & 385 & 66,7 & 30 & 5,2 & 89 & 15,4 & 49 & 8,5 \\
\hline 1962 & 13185 & 469 & 3,6 & 122 & 26,0 & 302 & 64,4 & 39 & 8,3 & 76 & 16,2 & 32 & 6,8 \\
\hline 1963 & 12563 & 470 & 3,7 & 113 & 24,0 & 319 & 67,9 & 26 & 5,5 & 76 & 16,2 & 32 & 6,8 \\
\hline 1964 & 11902 & 652 & 5,5 & 143 & 21,9 & 449 & 68,9 & 45 & 6,9 & 86 & 13,2 & 55 & 8,4 \\
\hline 1965 & 11321 & 752 & 6,6 & 169 & 22,5 & 560 & 74,5 & 50 & 6,6 & 79 & 10,5 & 29 & 3,9 \\
\hline 1966 & 10999 & 920 & 8,4 & 182 & 19,8 & 703 & 76,4 & 54 & 5,9 & 95 & 10,3 & 39 & 4,2 \\
\hline 1967 & 10548 & 926 & 8,8 & 165 & 17,8 & 708 & 76,5 & $\ldots$ & $\ldots$ & $\ldots$ & $\ldots$ & $\ldots$ & $\ldots$ \\
\hline 1968 & 10392 & 1107 & 10,7 & 211 & 19,1 & 864 & 78,0 & $\ldots$ & $\ldots$ & $\ldots$ & $\ldots$ & $\ldots$ & $\ldots$ \\
\hline 1969 & 10714 & 1157 & 10,8 & 170 & 14,7 & 919 & 79,4 & $\ldots$ & $\ldots$ & $\ldots$ & $\ldots$ & $\ldots$ & $\ldots$ \\
\hline 1970 & 11481 & 1245 & 10,8 & 167 & 13,4 & 990 & 79,5 & $\ldots$ & $\ldots$ & $\ldots$ & $\ldots$ & $\ldots$ & $\ldots$ \\
\hline 1971 & 11820 & 1205 & 10,2 & $\ldots$ & $\ldots$ & 944 & 78,3 & $\ldots$ & $\ldots$ & $\ldots$ & $\ldots$ & $\ldots$ & $\ldots$ \\
\hline 1972 & 12306 & 1273 & 10,3 & 136 & 10,7 & 1021 & 80,2 & $\ldots$ & $\ldots$ & $\ldots$ & $\ldots$ & $\ldots$ & $\ldots$ \\
\hline 1973 & 12167 & 1180 & 9,7 & 104 & 8,8 & 937 & 79,4 & ... & $\ldots$ & $\ldots$ & $\ldots$ & $\ldots$ & $\ldots$ \\
\hline
\end{tabular}


Таблица 2 (продолжение)

\begin{tabular}{|c|c|c|c|c|c|c|c|c|c|c|c|c|c|}
\hline \multirow{3}{*}{ Год } & \multirow{3}{*}{ 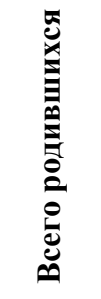 } & \multirow{2}{*}{\multicolumn{2}{|c|}{$\begin{array}{c}\text { в т.ч. y } \\
\text { женщин до } \\
20 \text { лет }\end{array}$}} & \multirow{2}{*}{\multicolumn{2}{|c|}{$\begin{array}{c}\text { в т.ч. } \\
\text { родившиеся } \\
\text { вне брака } \\
\text { русские }\end{array}$}} & \multicolumn{8}{|c|}{ в т.ч. родившиеся по национальности матери } \\
\hline & & & & & & \multicolumn{2}{|c|}{ украинцы } & \multicolumn{2}{|c|}{ белорусы } & \multicolumn{2}{|c|}{ литовцы } & \multirow[b]{2}{*}{ абс. } & \multirow[b]{2}{*}{$\%$} \\
\hline & & абс. & $\%$ & аббс. & $\%$ & аб̆c. & $\%$ & абс. & $\%$ & абс. & $\%$ & & \\
\hline 1974 & 12390 & 1400 & 11,3 & 160 & 11,4 & 1109 & 79,2 & $\ldots$ & $\ldots$ & $\ldots$ & $\ldots$ & $\ldots$ & $\ldots$ \\
\hline 1975 & 12465 & 1334 & 10,7 & 148 & 11,1 & 1068 & 80,1 & $\ldots$ & $\ldots$ & $\ldots$ & $\ldots$ & $\ldots$ & $\ldots$ \\
\hline 1976 & 12879 & 1537 & 11,9 & 161 & 10,5 & 1211 & 78,8 & $\ldots$ & $\ldots$ & $\ldots$ & $\ldots$ & $\ldots$ & $\ldots$ \\
\hline 1977 & 13078 & 1505 & 11,5 & 170 & 11,3 & 1171 & 77,8 & $\ldots$ & $\ldots$ & $\ldots$ & $\ldots$ & $\ldots$ & $\ldots$ \\
\hline 1978 & 12803 & 1570 & 12,3 & 174 & 11,1 & 1229 & 78,3 & 66 & 4,2 & 140 & 8,9 & $\ldots$ & $\ldots$ \\
\hline 1979 & 12696 & 1544 & 12,2 & 180 & 11,7 & 1214 & 78,6 & 78 & 5,1 & 134 & 8,7 & $\ldots$ & $\ldots$ \\
\hline 1980 & 12471 & 1468 & 11,8 & 173 & 11,8 & 1149 & 78,3 & 85 & 5,8 & 139 & 9,5 & $\ldots$ & $\ldots$ \\
\hline 1981 & 12533 & 1402 & 11,2 & $\ldots$ & $\ldots$ & $\ldots$ & $\ldots$ & $\ldots$ & $\ldots$ & $\ldots$ & $\ldots$ & $\ldots$ & $\ldots$ \\
\hline 1982 & 12560 & 1354 & 10,8 & $\ldots$ & $\ldots$ & 1066 & 78,7 & $\ldots$ & $\ldots$ & $\ldots$ & $\ldots$ & $\ldots$ & $\ldots$ \\
\hline 1983 & 13637 & 1294 & 9,5 & $\ldots$ & $\ldots$ & 1017 & 78,6 & $\ldots$ & $\ldots$ & $\ldots$ & $\ldots$ & $\ldots$ & $\ldots$ \\
\hline 1984 & 13516 & 1366 & 10,1 & $\ldots$ & $\ldots$ & 1073 & 78,6 & $\ldots$ & $\ldots$ & $\ldots$ & $\ldots$ & $\ldots$ & $\ldots$ \\
\hline 1985 & 13159 & 1325 & 10,1 & $\ldots$ & $\ldots$ & 1000 & 75,5 & $\ldots$ & $\ldots$ & $\ldots$ & $\ldots$ & $\ldots$ & $\ldots$ \\
\hline 1986 & 13900 & 1318 & 9,5 & $\ldots$ & $\ldots$ & 978 & 74,2 & $\ldots$ & $\ldots$ & $\ldots$ & $\ldots$ & $\ldots$ & $\ldots$ \\
\hline 1987 & 13885 & 1465 & 10,6 & $\ldots$ & $\ldots$ & 1123 & 76,7 & $\ldots$ & $\ldots$ & $\ldots$ & $\ldots$ & $\ldots$ & $\ldots$ \\
\hline 1988 & 13242 & 1520 & 11,5 & 169 & 11,1 & $\ldots$ & $\cdots$ & $\cdots$ & $\ldots$ & ... & ... & $\ldots$ & $\ldots$ \\
\hline 1989 & 12010 & 1641 & 13,7 & 196 & 11,9 & 1327 & 80,9 & 113 & 6,9 & 85 & 5,2 & 72 & 4,4 \\
\hline 1990 & 11168 & 1768 & 15,8 & 214 & 12,1 & 1427 & 80,7 & 122 & 6,9 & 111 & 6,3 & 55 & 3,1 \\
\hline 1991 & 10511 & 1729 & 16,4 & 223 & 12,9 & 1416 & 81,9 & 103 & 6,0 & 90 & 5,2 & 45 & 2,6 \\
\hline 1992 & 9340 & 1709 & 18,3 & 332 & 19,4 & 1427 & 83,5 & $\ldots$ & $\ldots$ & $\ldots$ & $\ldots$ & $\ldots$ & $\ldots$ \\
\hline 1993 & 8104 & 1454 & 17,9 & 349 & 24,0 & 1162 & 79,9 & $\ldots$ & $\ldots$ & $\ldots$ & $\ldots$ & $\ldots$ & $\ldots$ \\
\hline 1994 & 8464 & 1584 & 18,7 & 402 & 25,4 & 1324 & 83,6 & $\ldots$ & $\ldots$ & $\ldots$ & $\ldots$ & $\ldots$ & $\ldots$ \\
\hline 1995 & 7946 & 1446 & 18,2 & 393 & 27,2 & 1232 & 85,2 & $\ldots$ & $\ldots$ & $\ldots$ & $\ldots$ & $\ldots$ & $\ldots$ \\
\hline 1996 & 7435 & 1269 & 17,1 & 376 & 29,6 & 1046 & 82,4 & $\ldots$ & $\ldots$ & $\ldots$ & $\ldots$ & $\ldots$ & $\ldots$ \\
\hline 1997 & 7135 & 1141 & 16,0 & 470 & 41,2 & $\ldots$ & $\ldots$ & $\ldots$ & $\ldots$ & $\ldots$ & $\ldots$ & $\ldots$ & $\ldots$ \\
\hline 1998 & 7673 & 1184 & 15,4 & 487 & 41,1 & $\ldots$ & $\ldots$ & $\ldots$ & $\ldots$ & $\ldots$ & $\ldots$ & $\ldots$ & $\ldots$ \\
\hline 1999 & 7075 & 1036 & 14,6 & 444 & 42,9 & $\ldots$ & $\ldots$ & $\ldots$ & $\ldots$ & $\ldots$ & $\ldots$ & $\ldots$ & $\ldots$ \\
\hline 2000 & 7573 & 970 & 12,8 & 439 & 45,3 & $\ldots$ & $\ldots$ & $\ldots$ & $\ldots$ & $\ldots$ & $\ldots$ & $\ldots$ & $\ldots$ \\
\hline 2001 & 7630 & 1068 & 14,0 & 509 & 47,7 & $\ldots$ & $\ldots$ & $\ldots$ & $\ldots$ & $\ldots$ & $\ldots$ & $\ldots$ & $\ldots$ \\
\hline 2002 & 8464 & 1047 & 12,4 & 513 & 49,0 & $\ldots$ & $\ldots$ & $\ldots$ & $\ldots$ & $\ldots$ & $\ldots$ & $\ldots$ & $\ldots$ \\
\hline 2003 & 8844 & 1098 & 12,4 & 529 & 48,2 & $\ldots$ & $\ldots$ & $\ldots$ & $\ldots$ & $\ldots$ & $\ldots$ & $\ldots$ & $\ldots$ \\
\hline 2004 & 8654 & 1006 & 11,6 & 511 & 50,8 & $\ldots$ & $\ldots$ & $\ldots$ & $\ldots$ & $\ldots$ & $\ldots$ & $\ldots$ & $\ldots$ \\
\hline 2005 & 8423 & 957 & 11,4 & 478 & 49,9 & $\ldots$ & $\ldots$ & $\ldots$ & $\ldots$ & $\ldots$ & $\ldots$ & $\ldots$ & $\ldots$ \\
\hline 2006 & 8754 & 1037 & 11,8 & 485 & 46,8 & $\ldots$ & $\ldots$ & $\ldots$ & $\ldots$ & $\ldots$ & $\ldots$ & $\ldots$ & \\
\hline
\end{tabular}


Таблица 2 (продолжение)

\begin{tabular}{|c|c|c|c|c|c|c|c|c|c|c|c|c|c|}
\hline \multirow{3}{*}{ Год } & \multirow{3}{*}{ 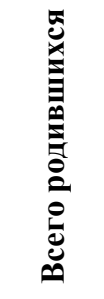 } & \multirow{2}{*}{\multicolumn{2}{|c|}{$\begin{array}{c}\text { в т.ч. y } \\
\text { женщин до } \\
20 \text { лет }\end{array}$}} & \multirow{2}{*}{\multicolumn{2}{|c|}{$\begin{array}{c}\text { в т.ч. } \\
\text { родившиеся } \\
\text { вне брака } \\
\text { русские }\end{array}$}} & \multicolumn{8}{|c|}{ в т.ч. родившиеся по национальности матери } \\
\hline & & & & & & \multicolumn{2}{|c|}{ украинцы } & \multicolumn{2}{|c|}{ белорусы } & \multicolumn{2}{|c|}{ литовцы } & \multirow[b]{2}{*}{ абс. } & \multirow[b]{2}{*}{$\%$} \\
\hline & & абсc. & $\%$ & абс. & $\%$ & абс. & $\%$ & абс. & $\%$ & абс. & $\%$ & & \\
\hline 2007 & 10200 & 938 & 9,2 & 469 & 50,0 & $\cdots$ & $\cdots$ & $\ldots$ & $\ldots$ & $\cdots$ & $\ldots$ & $\ldots$ & $\ldots$ \\
\hline 2008 & 10589 & 869 & 8,2 & 438 & 50,4 & $\ldots$ & $\ldots$ & $\ldots$ & $\ldots$ & $\ldots$ & $\ldots$ & $\ldots$ & $\ldots$ \\
\hline 2009 & 10823 & 787 & 7,3 & 374 & 47,5 & $\ldots$ & $\ldots$ & $\ldots$ & $\ldots$ & $\ldots$ & $\ldots$ & $\ldots$ & $\ldots$ \\
\hline 2010 & 10699 & 628 & 5,9 & 289 & 46,0 & $\ldots$ & $\ldots$ & $\ldots$ & $\ldots$ & $\ldots$ & $\ldots$ & $\ldots$ & $\ldots$ \\
\hline 2011 & 11102 & 565 & 5,1 & 282 & 49,9 & $\ldots$ & $\ldots$ & $\ldots$ & $\ldots$ & $\ldots$ & $\ldots$ & $\ldots$ & $\ldots$ \\
\hline 2012 & 11819 & 550 & 4,7 & 262 & 47,6 & $\ldots$ & $\ldots$ & $\ldots$ & $\ldots$ & $\ldots$ & $\ldots$ & $\ldots$ & $\ldots$ \\
\hline 2013 & 11924 & 476 & 4,0 & 237 & 49,8 & $\ldots$ & $\ldots$ & $\ldots$ & $\ldots$ & $\ldots$ & $\ldots$ & $\ldots$ & $\ldots$ \\
\hline 2014 & 12182 & 496 & 4,1 & 248 & 50,0 & $\ldots$ & $\ldots$ & $\ldots$ & $\ldots$ & $\ldots$ & $\ldots$ & $\ldots$ & $\ldots$ \\
\hline 2015 & 12399 & 432 & 3,5 & 209 & 48,4 & $\ldots$ & $\ldots$ & $\ldots$ & $\ldots$ & $\ldots$ & $\ldots$ & $\ldots$ & $\ldots$ \\
\hline 2016 & 12189 & 377 & 3,1 & 175 & 46,4 & $\ldots$ & $\ldots$ & $\ldots$ & $\ldots$ & $\ldots$ & $\ldots$ & $\ldots$ & $\ldots$ \\
\hline 2017 & 10876 & 339 & 3,1 & 162 & 47,8 & $\ldots$ & $\ldots$ & $\ldots$ & $\ldots$ & $\ldots$ & $\ldots$ & $\ldots$ & $\ldots$ \\
\hline 2018 & 10326 & 283 & 2,7 & 143 & 50,5 & $\ldots$ & $\ldots$ & $\ldots$ & $\ldots$ & $\ldots$ & $\ldots$ & $\ldots$ & $\ldots$ \\
\hline 2019 & 9293 & 287 & 3,1 & 126 & 43,9 & $\ldots$ & $\ldots$ & $\ldots$ & $\ldots$ & $\ldots$ & $\ldots$ & $\ldots$ &. \\
\hline
\end{tabular}

Обратим внимание на то, как менялся удельный вес родившихся вне брака у женщин моложе 20 лет. Довольно высокие показатели были характерны для первой половины 1960-х годов, после чего они снизились и оставались практически неизменными на протяжении 1970-х - 1980-х годов. Однако с 1992 г. наметился стремительный рост внебрачной рождаемости (таблица 2). Причем до 2003 г. увеличивалось как общее количество родившихся вне брака, так и их удельный вес. С 2004 г. количество внебрачных рождений у юных матерей стало ежегодно сокращаться, но доля внебрачных рождений по сей день остается очень высокой - практически половина от всех родившихся (таблица 2).

Сведения об этническом составе младенцев, родившихся у матерей определенного возраста, являются довольно скудными. В статистических сводках такие данные представлены только до 1996 г. Причем, систематически фиксировалось число новорожденных у матерей русской национальности (таблица 2). Сведения по другим национальностям в статистических отчетах появлялись не регулярно. Более того, в архивах встречаются документы, в которых делались замечания по поводу поступавшей из регионов подробной информации о родившихся по конкретной национальности матери. Так, в июле 1967 г. в Статистическое Управление Калининградской области поступило письмо из ЦСУ РСФСР в котором было сделано замечание: «Отдел статистики населения и здравоохранения ЦСУ РСФСР сообщает, что форма 2 «Сведения о родившихся по возрасту и национальности матери» представляется в ЦСУ РСФСР на все национальности и отдельно на русских, все остальные формы возвращаем как лишние» (ГАКО. Д. 261. Л. 90). 


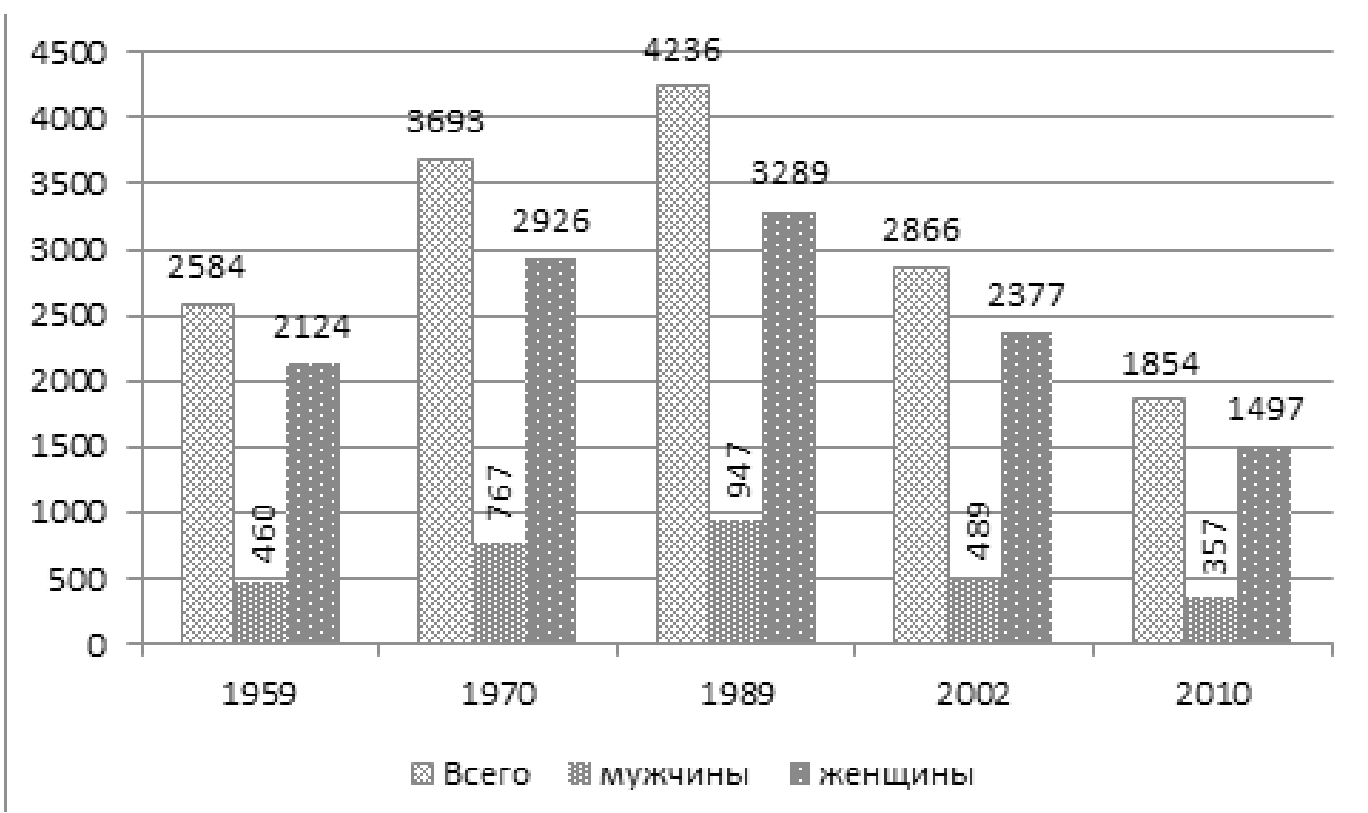

Рис. 3. Распределение населения Калининградской области по состоянию в браке на момент проведения переписей населения.

Имеющиеся в нашем распоряжении данные позволяют сделать вывод, что большая часть рожениц Калининградской области, в том числе в возрасте до 20 лет, считали себя русскими. Причем, если в первой половине 1960-х годов русскими себя назвали чуть более двух третей молодых женщин, то с середины 1960-х до конца 1980-х годов уже более трех четвертей, а с конца 1980-х годов - более 80\% (таблица 2). При этом доля родившихся у молодых женщин украинской национальности практически не изменилась, а вот удельный вес появившихся на свет у женщин белорусской и литовской национальностей существенно снизился (таблица 2). Но, несмотря на изменения в соотношении женщин разных национальностей, все же более 95\% молодых матерей относили себя к одной из четырех национальностей - русские, белорусы, украинцы и литовцы, что соответствовало этнической структуре населения области.

Брачное поведение и семейные установки молодежи Калининградской области.

Брачный статус человека играет значительную роль в демографических процессах. Браки оказывают определенное влияние на рождаемость и иллюстрируют отношение людей к такому институту, как семья. Так, на момент проведения переписи 1959 г. в Калининградской области в браке состояло 61,5\% людей в возрасте 15 лет и старше, в 1970 г. - 63,6\%, в 1989 г. - 65,7\%. Однако переписи постсоветского периода демонстрируют снижение удельного веса состоявших в браке людей: 2002 г. - 56,6\%; 2010 г. - 54,8\% (Демоскоп). Во многом это произошло за счет сокращения количества состоявших в браке людей молодых возрастов, в том числе в возрасте до 20 лет (рис. 3). К сожалению, только в двух постсоветских переписях зафиксированы сведения об официально зарегистрированных и не зарегистрированных браках: 2002 г. - 1752 и 1114; 2010 г. - 918 и 936, соответственно (Демоскоп). Но, несмотря на сокращение количества браков, доля официально не зарегистрированных союзов среди юношей и девушек до 20 лет значительно увеличилась: 2002 г. - 38\%; 2010 г. - 50,5\%. 
Что касается ежегодно заключаемых браков, то на протяжении 1960-1980-х годов их количество в Калининградской области не являлось стабильным, хотя не наблюдалось и кардинального изменения показателей (таблица 3). Безусловно, количество регистрируемых браков не было одинаковым каждый год, однако, резких перепадов не отмечалось вплоть до 1992 г., когда произошло существенное сокращение их числа. Ежегодные показатели колебались на протяжении 1990-х - начала 2000-х годов, но с 2007 г. обозначился рост, который начал вновь снижаться с 2015 г. Насколько продолжительной будет данная тенденция, зависит от показателей брачности во всех возрастных группах, в том числе и среди молодежи до 20 лет. Отметим, что со второй половины 1960-х годов прослеживается увеличение количества браков, где хотя бы один из супругов был моложе 20 лет (таблица 3). Именно с этого времени такие союзы составляли практически одну треть среди ежегодно регистрируемых браков: 1966 г. - 30,5\%; 1968 г. - 35,1\%; 1970 г. - 32,7\%; 1975 г. - 31,3\%; 1977 г. $33,4 \%$; 1980 г. $-32,6 \%$; 1985 г. $-28,1 \%$; 1988 г. $-30,2 \%$; 1989 г. $-36,4 \%$; 1990 г. 38,8\%; 1991 г. - 40,7\% (подсчитано на основе таблицы 3). С 1992 г. сокращается и количество, и удельный вес браков в которых хотя бы один из супругов был моложе 20 лет: 1992 г. - 38,2\%; 1993 г. - 37,6\%; 1994 г. - 35,3\%; 1995 г. - 32,4\%; 1996 г. $28,9 \%$ (подсчитано на основе таблицы 3 ).

Таблица 3

Вступившие в брак на территории Калининградской области

\begin{tabular}{|c|c|c|c|c|c|c|c|}
\hline \multirow{2}{*}{ Год } & \multirow{2}{*}{$\begin{array}{c}\text { Всего } \\
\text { вступивших } \\
\text { в брак }\end{array}$} & \multicolumn{2}{|c|}{$\begin{array}{c}\text { в том числе в } \\
\text { возрасте до } 20 \text { лет }\end{array}$} & \multirow{2}{*}{ Год } & \multirow{2}{*}{$\begin{array}{c}\text { Всего } \\
\text { вступивших } \\
\text { в брак }\end{array}$} & \multicolumn{2}{|c|}{$\begin{array}{c}\text { в том числе в } \\
\text { возрасте до } 20 \text { лет }\end{array}$} \\
\hline & & мужчин & женщин & & & мужчин & женщин \\
\hline 1958 & 9288 & 294 & 1480 & 1989 & 8637 & 631 & 2510 \\
\hline 1959 & 8787 & 320 & 1571 & 1990 & 8819 & 740 & 2685 \\
\hline 1960 & 9510 & 379 & 1589 & 1991 & 8636 & 764 & 2749 \\
\hline 1961 & 8423 & 271 & 1161 & 1992 & 6979 & 568 & 2101 \\
\hline 1962 & 7874 & 188 & 927 & 1993 & 7274 & 521 & 2217 \\
\hline 1963 & 7324 & 191 & 998 & 1994 & 7381 & 514 & 2093 \\
\hline 1964 & 7150 & 248 & 1181 & 1995 & 7230 & 444 & 1902 \\
\hline 1965 & 7030 & 366 & 1577 & 1996 & 5705 & 276 & 1370 \\
\hline 1966 & 7662 & 481 & 1857 & 1997 & 6298 & $\ldots$ & $\ldots$ \\
\hline 1967 & 7895 & 525 & 1966 & 1998 & 5940 & $\ldots$ & $\ldots$ \\
\hline 1968 & 8068 & 622 & 2209 & 1999 & 6059 & $\ldots$ & $\ldots$ \\
\hline 1969 & 8641 & 616 & 2392 & 2000 & 6190 & $\ldots$ & $\ldots$ \\
\hline 1970 & 8737 & 565 & 2288 & 2001 & 6648 & $\ldots$ & $\ldots$ \\
\hline 1971 & 9422 & 546 & 2386 & 2002 & 6522 & $\ldots$ & $\ldots$ \\
\hline 1972 & 8928 & 453 & 2164 & 2003 & 7000 & $\ldots$ & $\ldots$ \\
\hline 1973 & 9405 & 466 & 2457 & 2004 & 6755 & $\ldots$ & $\ldots$ \\
\hline 1974 & 9597 & 477 & 2452 & 2005 & 7513 & $\ldots$ & $\ldots$ \\
\hline 1975 & 10110 & 499 & 2661 & 2006 & 7959 & $\ldots$ & $\ldots$ \\
\hline
\end{tabular}


Таблица 3 (продолжение)

\begin{tabular}{|c|c|c|c|c|c|c|c|}
\hline \multirow{2}{*}{ Год } & \multirow{2}{*}{$\begin{array}{c}\text { Всего } \\
\text { вступивших } \\
\text { в брак }\end{array}$} & \multicolumn{2}{|c|}{$\begin{array}{c}\text { в том числе в } \\
\text { возрасте до } 20 \text { лет }\end{array}$} & \multirow{2}{*}{ Год } & \multirow{2}{*}{$\begin{array}{c}\text { Всего } \\
\text { вступивших } \\
\text { в брак }\end{array}$} & \multicolumn{2}{|c|}{$\begin{array}{c}\text { в том числе в } \\
\text { возрасте до } 20 \text { лет }\end{array}$} \\
\hline & & мужчин & женщин & & & мужчин & женщин \\
\hline 1976 & 9962 & 579 & 2660 & 2007 & 8794 & $\ldots$ & $\ldots$ \\
\hline 1977 & 10282 & 573 & 2861 & 2008 & 8702 & $\ldots$ & $\ldots$ \\
\hline 1978 & 9721 & 584 & 2716 & 2009 & 8208 & $\ldots$ & $\ldots$ \\
\hline 1979 & 9841 & 637 & 2628 & 2010 & 8552 & $\ldots$ & $\ldots$ \\
\hline 1980 & 9565 & 596 & 2523 & 2011 & 9034 & 118 & 542 \\
\hline 1981 & 9431 & 597 & 2441 & 2012 & 9177 & 92 & 535 \\
\hline 1982 & 9346 & 532 & 2279 & 2013 & 8960 & 90 & 478 \\
\hline 1983 & 9586 & 551 & 2258 & 2014 & 9121 & 93 & 471 \\
\hline 1984 & 9008 & 511 & 2009 & 2015 & 8392 & 85 & 424 \\
\hline 1985 & 9184 & 499 & 2085 & 2016 & 7441 & 73 & 355 \\
\hline 1986 & 9484 & 481 & 2231 & 2017 & 7828 & 63 & 385 \\
\hline 1987 & 9291 & 451 & 2181 & 2018 & 7024 & 58 & 292 \\
\hline 1988 & 9184 & 519 & 2253 & 2019 & 7421 & $\ldots$ & $\ldots$ \\
\hline
\end{tabular}

К сожалению, в нашем распоряжении отсутствуют данные с 1997 по 2010 гг. Очевидно, что именно в данный промежуток времени возник перелом в брачном поведении молодежи, поскольку в 2011 г. удельный вес таких браков составил всего 7,3\% от общего количества заключенных браков, в 2015 г. - 6,1\%, в 2018 г. - 5,0\% (подсчитано на основе таблицы 3). Таким образом, у парней и девушек практически отсутствует ориентация на заключение брака и создание семьи в столь юном возрасте.

Заключение. Итак, проведенный анализ данных продемонстрировал, что за прошедшие шестьдесят лет репродуктивное поведение молодежи Калининградской области кардинальным образом изменилось. На это повлияли такие факторы, как рост образованности, стремление к достижению определенного уровня благосостояния, индивидуальное планирование семьи, широкое использование контрацептивов, достаточная осведомленность об особенностях интимной жизни через средства массовой информации, сложившееся в семьи и обществе нейтральное отношение к совместному проживанию молодых людей вне зарегистрированного брака, а также стремление самих девушек и парней отложить создание семьи на более поздний возраст.

\section{Источники и материалы}

Всероссийская 2010 - Всероссийская перепись населения 2010 года. Территориальный орган Федеральной службы государственной статистики по Калининградской области. Доступ: https://kalinin grad.gks.ru/National_Population_Census_2010 (дата обращения: 12.12.2020).

ГАКО - Государственный архив Калининградской области. Ф.Р-181 (Статистическое управление Калининградской области).

Демоскоп - Демоскоп-Weekly. Институт демографии. НИУ ВШЭ. Приложения. Доступ: http://www.demoscope.ru/weekly/pril.php (дата обращения: 15.12.2020).

Демографический ежегодник Калининградской области. 1998 год. Калининград, 1998. 
Демографический 2000 - Демографический ежегодник. Калининградская область. 2000 год. Калининград: Калининградстат, 2000.

Демографический 2009 - Демографический ежегодник. Калининградская область. 2009 год. Калининград: Калининградстат, 2009.

Демографический 2018 - Демографический ежегодник. Калининградская область. 2018 год. Калининград: Калининградстат, 2018.

Демографический 2019 - Демографический ежегодник. Калининградская область. 2019 год. Калининград: Калининградстат, 2019.

Закон 1968 - Закон от 27.06.1968 «Об утверждении основ законодательства Союза ССР и Союзных Республик о браке и семье». Доступ: http://www.libussr.ru/doc_ussr/usr_6840.htm (дата обращения 15.12.2020).

Основы 2014 - Основы государственной молодежной политики Российской Федерации на период до 2025 года. Утверждены распоряжением Правительства Российской Федерации от 29 ноября 2014 г. №2403-p. Доступ: http://static.government.ru/media/files/ceFXleNUqOU. pdf (дата обращения: 18.12.2020).

Семейный 1995 - Семейный кодекс Российской Федерации от 29.12.1995 №223-ФЗ. Доступ: http://www.semkod.ru/ (дата обращения: 20.12.2020).

Территориальный 2020 - Территориальный орган Федеральной службы государственной статистики по Калининградской области. Доступ: https://kaliningrad.gks.ru/population (дата обращения: 12.12.2020).

Федеральный 2020 - Федеральный Закон от 30.12.2020 № 489-Ф3 «О молодежной политике в Российской Федерации». Доступ: http://publication.pravo.gov.ru/Document/View/0001202 012300003? index $=0$ \&rangeSize $=1$ (дата обращения: 05.01.2021).

Федеральная 2020 - Федеральная служба государственной статистики. Доступ: https://rosstat. gov.ru/folder/12781 (дата обращения: 12.12.2020).

\section{Научная литература}

Горшков М.К., Шереги Ф.Э. Молодежь России в зеркале социологии: к итогам многолетних исследований. М.: ФНИСЦ РАН, 2020. 688 с.

Горшков М.К., Шереги Ф.Э. Молодежь России: социологический портрет. М.: ЦСПиМ, 2010.

Григорьева Р.А., Мартынова М.Ю. Школьники Калининградской области о своей идентичности (по результатам опроса) // Молодежь в малых городах России: заметки социального антрополога. М.: ИЭА РАН, 2016. С. 155-176.

Григорьева Р.А., Мартынова М.Ю. Молодежь в городах Калининградской области. Исследования по прикладной и неотложной этнологии. М.: ИЭА РАН, 2017. Вып. 260. 132 с.

Захарова О.Д., Акопян А.С., Харченко В.И. Эволюция рождаемости в России во второй половине XX века: история, современность и перспективы // Проблемы прогнозирования, 2002. № 6. С. 94-106.

Захаров С.В., Митрофанова Е.С. Демографические характеристики молодежи в России // Россия и Китай: молодежь ХХІ века. М.: Новый хронограф, 2014. С. 55-79.

Зимовина Е.П. Сравнительный анализ молодежи Еврорегиона Балтика (по результатам социологического исследования) // Проблемы межрегиональных связей = Problems of connections between regions: научный альманах. Вып. 14. Санкт-Петербург; Клайпеда; Калининград, 2019. С. 19-23.

Зимовина Е.П., Щекотуров А.В., Кришталь М.И. Пространственная мобильность и миграционные установки реформенного поколения и поколения миллениалов Калининградской области // Вестник Балтийского федерального университета им.И.Канта. Сер.: Гуманитарные и общественные науки. 2020. № 2. С .86-105.

Козырева П.М., Лежнина Ю.П. Российская молодежь: семья, брак и сексуальность // Россия и Китай: молодежь XXI века. М.: Новый хронограф, 2014. С. 192-220. 
Костяшов Ю.В. О естественном движении населения в Калининградской области в 19461950 годах // Проблемы исторических и философских наук: материалы постоянных научных семинаров. Калининград: Калинингр. гос. ун-т, 2000. С. 3-9.

Костяшов Ю.В. Секретная история Калининградской области. Очерки 1945-1956 гг. Калининград: Терра Балтика, 2009. 351 с.

Кузнецова Т.Ю. Геодемографическая типология муниципальных образований Калининградской области // Вестник БФУ им.И.Канта. Серия: Естественные и медицинские науки. 2016. № 1. С. 15-27.

Кузнецова Т.Ю., Сибирева Н.И. Экономико-демографические различия муниципальных образований Калининградской области // Вестник БФУ им. И. Канта. Серия: Гуманитарные и общественные науки, 2020. № 1. С.43-55.

Манкевич Д. В. Калининградское село в условиях «демографической революции» (вторая половина 1940-х-1950-е годы): трансформация рождаемости // Северо-Запад в аграрной истории России: межвуз. темат. сб. науч. тр. Калининград: РГУ им. И. Канта, 2009. С. 226-233.

Мартынова М.Ю., Григорьева Р.А. Геополитическое положение Калининградской области и жизненные стратегии ее молодых жителей: оценка рисков // Вестник Дипломатической академии МИД России. Россия и мир, 2018. № 3 (17). С. 128-144.

Митрофанова E. (Не) время взрослеть: как меняется возраст наступления дебютных биографических событий у россиян // Демографическое обозрение, 2020. Том 7, № 4. С. 36-61.

Миронова С.Г. Кузьмина О.В. (сост.); Кузьмина О.В. (отв. за выл.) Молодежь России: сборник рефератов статей из периодических изданий за 2015 год. М.: Рос. гос. биб-ка для молодежи, 2016. $166 \mathrm{c.}$

Народонаселение: Энциклопедический словарь. М.: Большая Российская энциклопедия, 1994. $640 \mathrm{c}$.

Федоров Г.М. Население Калининградской области. Демографические условия обоснования Территориальной комплексной схемы градостроительного планирования развития территории Калининградской области и ее частей: Монография. Калининград: Изд-во КГУ, 2001. $111 \mathrm{c}$.

Федоров Г.М., Зверев Ю.М. Калининградские альтернативы: 25 лет спустя. Монография. Калининград: Изд-во БФУ им. И. Канта, 2020. 315 с.

Zimovina, Elena P.

\section{Youth of Kaliningrad Region: Reproductive Behavior from a Historical Perspective and at the Present Time}

DOI: $10.33876 / 2311-0546 / 2021-54-2 / 110-127$

The article examines the reproductive behavior of young people aged 15-19 years living in the Kaliningrad region. The work is based on archival documents, censuses data and the statistics covering sixty years (1959-2019). Analysis of statistical indicators suggests gradual reduction in the proportion of young people in the population structure of the region. On the one hand, this is the consequence of the decline in the birth rate during the studied period, on the other hand, it in turn affects the dynamics of the birth rate, especially at the present time. Particular attention is paid to fertility rates among women under 20 years of age. It is concluded that the contribution of the youngest women to the reproduction of the region's population has changed significantly over six decades. This was largely due to a change in the attitude of young people towards marriage, as evidenced by the increase in the number of extramarital affairs and the change in the number and proportion of children born out of wedlock. Thus, a definite connection was established between reproductive behavior and family and marriage attitudes of young people. 
Keywords: Kaliningrad Region, youth, reproductive behavior, reproductive age, family and marriage attitudes

For Citation: Zimovina, E.P. 2021. Youth of Kaliningrad Region: reproductive behavior from a historical perspective and at the present time. Herald of Anthropology (Vestnik Antropologii) 2: 110-127.

\section{Author Info:}

Zimovina, Elena P. - PhD in History, Senior Researcher of Sociological Laboratory, Immanuel Kant Baltic Federal University (236016, Kaliningrad, A.Nevskogo, 14). E-mail: ezimovina@kantiana.ru, zimelena@yandex.ru

Funding: The reported study was funded by RFBR and BRFBR, project number 20-59$00014 / 20$.

\section{References}

Fedorov, G.M. 2001. Naselenie Kaliningradskoi oblasti. Demograficheskie usloviia obosnovaniia Territorial'noi kompleksnoi skhemy gradostroitel'nogo planirovaniia razvitiia territorii Kaliningradskoi oblasti $i$ ee chastei [Population of Kaliningrad Region. Demographic conditions for substantiating the territorial complex scheme of urban planning and development of Kaliningrad Region and its parts]. Kaliningrad: Izdatelstvo Kaliningrad State University.

Fedorov, G.M., and Iu.M. Zverev. 2020. Kaliningradskie al'ternativy: 25 let spustia [Kaliningrad alternatives: 25 years later]. Kaliningrad: Izatelstvo Kant Baltik Federal University.

Gorshkov, M.K., and F.E. Sheregi. 2010. Molodezh'Rossii: sotsiologicheskii portret [Youth of Russia: sociological portrait]. Moscow: TsSPM.

Gorshkov, M.K., and F.E. Sheregi. 2020. Molodezh' Rossii v zerkale sotsiologii: $k$ itogam mnogoletnikh issledovanii [Russian Youth in the mirror of sociology: the results of research for some years]. Moscow: FNISTS RAN.

Grigorieva, R.A., and M.Yu. Martynova. 2016. Shkol'niki Kaliningradskoi oblasti o svoei identichnosti (po rezul'tatam oprosa) [Schoolchildren of Kaliningrad Region about their identity (based on the survey results)]. Molodezh'v malykh gorodakh Rossii: zametki sotsial'nogo antropologa. Moscow: Institute of Ethnology and Anthropology RAN.

Grigorieva, R.A., and M.Yu. Martynova. 2017. Molodezh' v gorodakh Kaliningradskoi oblasti [Youth in the towns of Kaliningrad region]. Issledovaniia po prikladnoi i neotlozhnoi etnologii 260. Moscow: Institute of Ethnology and Anthropology RAN.

Kostiashov, Iu.V. 2000. O estestvennom dvizhenii naseleniia v Kaliningradskoi oblasti v 19461950 godakh [About Natural Movement of Population in Kaliningrad Region in 1946-1950ss]. In Problemy istoricheskikh i filosofskikh nauk: materialy postoiannykh nauchnykh seminarov, 3-9. Kaliningrad: Kaliningrad State University.

Kostiashov, Iu.V. 2009. Sekretnaia istoriia Kaliningradskoi oblasti. Ocherki 1945-1956 gg [Secret History of Kaliningrad Region. Essays 1945-1956ss] Kaliningrad: Terra Baltika.

Kozyreva, P.M., and Iu.P. Lezhnina. 2014. Rossiiskaia molodezh': sem'ia, brak i seksual'nost' [Russian Youth: Family, Marriage and Sexuality]. In Rossiia i Kitai: molodezh' XXI veka, 192220. Moscow: Novyi khronograf.

Kuznetsova, T.Iu. 2016. Geodemograficheskaia tipologiia munitsipal'nykh obrazovanii Kaliningradskoi oblasti [Geodemographic classification of municipalities of Kaliningrad Region]. Vestnik Baltiiskogo federal'nogo universiteta im. I. Kanta. Seriia: Estestvennye $i$ meditsinskie nauk 1: 15-27.

Kuznetsova, T.Iu., N.I. Sibireva. 2020. Ekonomiko-demograficheskie razlichiia munitsipal'nykh obrazovanii Kaliningradskoi oblasti [Economic and Demographic Differences of municipalities 
of Kaliningrad Region]. Vestnik Baltiiskogo federal'nogo universiteta im. I. Kanta. Seriia: Gumanitarnye i obshchestvennye nauki 1: 43-55.

Mankevich, D. V. 2009. Kaliningradskoe selo v usloviiakh "demograficheskoi revoliutsii" (vtoraia polovina 1940-1950-e gody): transformatsiia rozhdaemosti [Kaliningrad village in the conditions of "Demographic Revolution" (second half of 1940-1950ss)]. Severo-Zapad v agrarnoi istorii Rossii: mezhvuz. temat. sb. nauch. tr., 226-233. Kaliningrad: Kant Kaliningrad State University.

Martynova, M.Yu., R.A. Grigorieva. 2018. Geopoliticheskoe polozhenie Kaliningradskoi oblasti i zhiznennye strategii molodykh zhitelei: otsenka riskov [Geopolitical situation of Kaliningrad Region and life strategies of the young inhabitants: risks assessment]. Vestnik Diplomaticheskoi akademii MID Rossii. Rossiia i mir 3 (17): 128-144.

Mironova, S.G. O.V. Kuzmina (eds.); and O.V. Kuzmina (responsible for the issue). 2016. Molodezh' Rossii: sbornik referatov, statei iz periodicheskikh izdanii za 2015 god [Youth of Russia: collection of essays, papers and periodicals]. Moscow: Rossiyskaya gosudarstvennaya biblioteka dlia molodezhi.

Mitrofanova, E. 2020. (Ne)vremia vzroslet': kak meniaetsia vozrast nastupleniia debiutnykh biograficheskikh sobytii u rossiian [(No)time to grow up: changing ages of debut biographical events in Russia]. Demograficheskoe obozrenie 7 (4): 36-61. https://demreview.hse.ru/.

Narodonaselenie: Entsiklopedicheskii slovar' [Population: Encyclopedic Dictionary]. 1994. Moscow: Bol'shaia Rossiiskaia entsiklopediia.

Zakharov, S.V., Mitrofanova, E.S. 2014. Demograficheskie kharakteristiki molodezhi v Rossii [Demographic Characteristics of the Youth in Russia]. Rossiia i Kitai: molodezh' XXI veka, 55-79. Moscow: Novyi khronograf.

Zakharova, O.D., A.S. Akopian, and V.I. Kharchenko. 2002. Evoliutsiia rozhdaemosti v Rossii vo vtoroi polovine XX veka: istoriia, sovremennost' i perspektivy [Evolution of fertility in Russia in the second part of XX Century: History, Contemporary and Prospects]. Problemy prognozirovaniia 6: 94-106.

Zimovina, E.P. 2019. Sravnitel'nyi analiz molodezhi Evroregiona Baltika (po rezul'tatam sotsiologicheskogo issledovaniia) [Contemporary Analysis of the Youth of Baltic Euroregion (based on sociological survey)]. Problemy mezhregional'nykh sviazei=Problems of connections between regions: nauchnyi al'manakh, 19-23. Vol. 14. Sankt-Peterburg; Klaipeda; Kaliningrad.

Zimovina, E.P., A.V. Shchekoturov, and M.I. Krishtal 2020. Prostranstvennaia mobil'nost' i migratsionnye ustanovki reformennogo pokoleniia i pokoleniia millenialov Kaliningradskoi oblasti [Territorial mobility and migration aims of Reform Generation and Millennials of Kaliningrad Region]. Vestnik Baltiiskogo federal'nogo universiteta im.I.Kanta. Ser.: Gumanitarnye i obshchestvennye nauki 2: 86-105. 